\title{
Interaction of molten salts in the systems $\mathrm{SiO}_{2}-\mathrm{Al}_{2} \mathrm{O}_{3}$
}

\section{(Interação de sais fundidos no sistema $\mathrm{SiO}_{2}-\mathrm{Al}_{2} \mathrm{O}_{3}$ )}

\author{
E. Grambálová, P. Vadász, J. Petrík \\ Faculty of Metallurgy, Technical University of Košice, Letná 9, 04200 Košice, Slovak Republic
}

\begin{abstract}
The aim of this study was to realize and evaluate laboratory corrosion tests for a solution of problems such as wear of refractory materials at processing of aluminum, for example. The static crucible corrosion tests were carried out in laboratory resistive furnace at $850^{\circ} \mathrm{C}$ during $2 \mathrm{~h}$ air atmosphere. Two standards of alumina-silica shaped refractory bricks were used as a corroding material. Pure sodium chloride and potassium chloride were applied as a corrosive media. The results of tests were evaluated by macroscopic, microscopic, chemical and semiquantitative EDX analysis. Sodium chloride shows more significant penetration and chemical interaction in penetrated area. EDX analysis confirms creation of the reaction layer between chlorides and elements of refractory lining. The products of reactions penetrate more deeply into $\mathrm{A}$ lining. $\mathrm{K}$ ions penetrate into the grains of the lining more intense than $\mathrm{Na}$ ions.
\end{abstract}

Keywords: chloride melts, static crucible corrosion test, alumina-silica refractory bricks.

\section{Resumo}

A finalidade deste estudo foi realizar e avaliar testes de laboratório de corrosão para a solução de problemas tais como desgaste de materiais refratários no processamento de alumínio, por exemplo. Os testes de corrosão estáticos em cadinhos foram feitos em forno resistivo de laboratório a $850{ }^{\circ} \mathrm{C}$ durante $2 \mathrm{~h}$ ao ar. Dois padrões de tijolos refratários sílico-aluminosos foram usados como material sob corrosão. Cloreto de sódio e cloreto de potássio puros foram aplicados como meios corrosivos. Os resultados dos testes foram avaliados por análise EDX semi-quantitativa macroscópica, microscópica, química. O cloreto de sódio mostrou mais significativa penetração e interação química na área penetrada. A análise de EDX confirma a criação de uma camada de reação entre os cloretos e os elementos de revestimento refratário. Os produtos da reação penetram mais profundamente no revestimento A. Os ions potássio penetram nos grãos do revestimento mais intensamente que os íons sódio.

Palavras-chave: cloretos fundidos, teste de corrosão estáticos em cadinho, tijolos refratários sílico-aluminosos.

\section{INTRODUCTION}

Aluminum is the third most abundant element in the crust of the earth. It makes up about $8 \%$ by weight of its solid surface. Aluminum does not occur in metallic form in contrast to other metals (copper, gold, silver). The technology of its production is complicated and it is energy intensive. Aluminum is extracted in two stages. First, relatively pure aluminum oxide is made, and then it is reduced to aluminum in electrolytic process. Obtained aluminum is refined to higher purity in setting furnaces as follows. The refining, covering and drossing fluxes (salts) are used for the covering the surface of melting aluminum in the furnaces in order to reduce the oxidation of melting. To minimize penetration of the atmospheric hydrogen, keep the furnace wall clean from the built up oxides, decrease the content of aluminum entrapped in the dross, remove hydrogen dissolved in the melting, provide aluminum grain refining during solidification, modify silicon inclusions in silicon containing alloys, increasing of recovery and thermal efficiency are other function of the fluxes.

The aim of this study is monitoring the influence of melting sodium chloride $(\mathrm{NaCl})$ and potassium chloride $(\mathrm{KCl})$ on alumina-silica refractory bricks or lining used in refining and processing of aluminum.

\section{MATERIALS, EQUIPMENTS AND METHODS}

Two standards (A, B) of fire-clay (chamotte) aluminumsilica shaped refractory bricks or the lining with varying rate of acid oxide $\mathrm{SiO}_{2}$ and amphoteric $\mathrm{Al}_{2} \mathrm{O}_{3}$ were used as corroded material. Their basic chemical composition is in Table I and also can be seen in Fig. 1. Some physicalmechanical properties of both standards are very similar regard to data in Table II. Both standards were analyzed by X-ray diffraction. The results are in Fig. 2. Both linings consist of mullite $\left(3 \mathrm{Al}_{2} \mathrm{O}_{3} 2 \mathrm{SiO}_{2}\right.$ or $\left.2 \mathrm{Al}_{2} \mathrm{O}_{3} \mathrm{SiO}_{2}\right)$ and amorphous phase based on $\mathrm{SiO}_{2}$, generated in thermal process of refractory clay. The diffractograms present mullite as majority phase. 
Table I - Chemical composition of refractory lining [1].

[Tabela I - Composição química do revestimento refratário [1].]

\begin{tabular}{ccccccccc}
\hline \multirow{2}{*}{ Lining } & \multicolumn{7}{c}{ Chemical phase [wt.\%] } \\
\cline { 2 - 8 } & $\mathrm{SiO}_{2}$ & $\mathrm{Al}_{2} \mathrm{O}_{3}$ & $\mathrm{Fe}_{2} \mathrm{O}_{3}$ & $\mathrm{TiO}_{2}$ & $\mathrm{CaO}$ & $\mathrm{MgO}$ & $\mathrm{Na}_{2} \mathrm{O}$ & $\mathrm{K}_{2} \mathrm{O}$ \\
$\mathrm{A}$ & 50.00 & 43.61 & 1.54 & 0.82 & 0.55 & 0.23 & 0.20 & 0.82 \\
$\mathrm{~B}$ & 63.00 & 26.00 & 2.00 & 1.00 & 1.50 & 1.00 & 0.29 & 1.13 \\
\hline
\end{tabular}

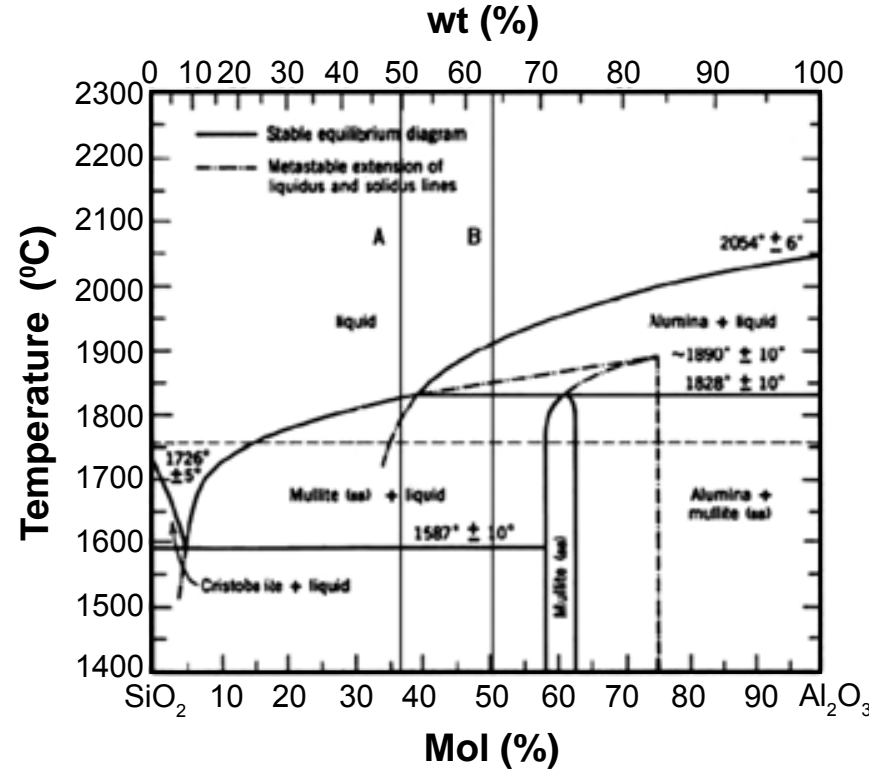

Figure 1: Phase diagram of $\mathrm{SiO}_{2}-\mathrm{Al}_{2} \mathrm{O}_{3}$ [2].

[Figura 1: Diagrama de fases de $\mathrm{SiO}_{2}-\mathrm{Al}_{2} \mathrm{O}_{3}$.]

The refractory lining B consists also of dravite and cristobalite in addition to mullite. The dravite is complex magnesium-sodium borosilicate $\mathrm{NaMg}_{3} \mathrm{Al}_{6}\left(\mathrm{BO}_{3}\right)_{3} \mathrm{Si}_{6} \mathrm{O}_{18}(\mathrm{OH})_{4}$ crystallizing in trigonal system. It can be ranked among tourmaline mineral group. The mineral cristobalite is a hightemperature polymorph of silica with the same chemical formula, $\mathrm{SiO}_{2}$, but a distinct crystal structure.

Pure (p.a.) $\mathrm{NaCl}$ and $\mathrm{KCl}$ (producer LACHEMA, Brno) were used as the corrosive medium. The salts were dried 10 $\mathrm{h}$ at $110^{\circ} \mathrm{C}$ before application. Some of their basic properties are in Table III.

The results of corrosion tests were evaluated by macroscopic, microscopic, chemical and semiquantitative EDX analysis. The specimens sampled from crucible's wall were observed by optic microscope Neophot 32 in reflected and polarized light and by scanning electron microscope. The penetrations were evaluated by semiquantitative local EDX element analysis using an electron microscope JEOL 35CF (SEM with a LINK AN 10,000 dispersive X-ray analyzer). The crystalline phases of lining were identified in X-ray powder diffractometer DRON 3-M using cobalt radiation.

The interaction of refractory lining and the melting of chlorides were tested by static corrosive crucible (or cup) test. The shaped refractory bricks were cut into prisms about $60 \mathrm{~mm} \quad 60 \mathrm{~mm} \quad 90 \mathrm{~mm}$ with diamond saw. The
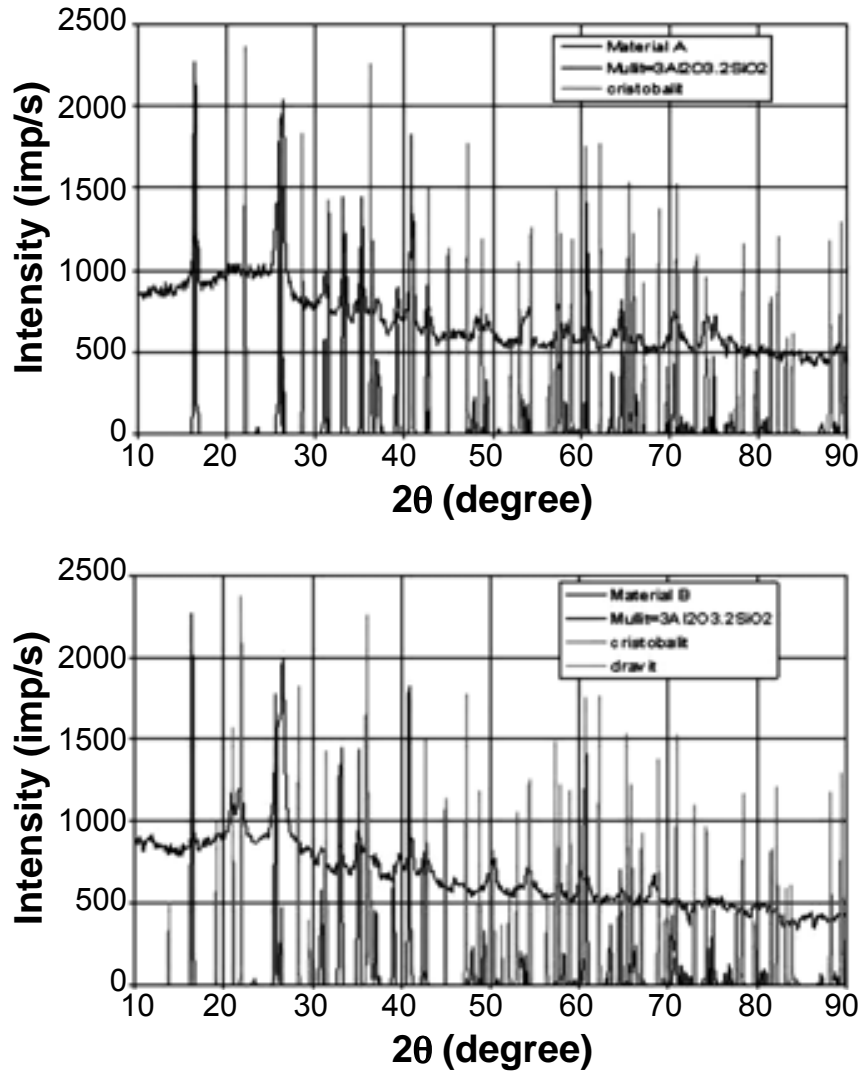

Figure 2: X-ray diffraction patterns of A and B refractory lining. [Figura 2: Difratogramas de raios $X$ dos revestimentos $A$ e B.]

holes with diameter $25 \mathrm{~mm}$ and depth $30 \mathrm{~mm}$ were drilled into prisms and filled with $15 \mathrm{~g}$ of dried $\mathrm{NaCl}$ or $\mathrm{KCl}$. The crucibles were heated in laboratory resistance furnace under air atmosphere $\left(\mathrm{p}_{\mathrm{O} 2} \sim 212.78 \mathrm{kPa}\right)$ at $850^{\circ} \mathrm{C}$ with dwell time $2 \mathrm{~h}$. Experimental temperature $850{ }^{\circ} \mathrm{C}$ was chosen pursuant to the melting temperature of corrosive medium (Table III) to ensure the homogeneity of the melting for a period of the test.

The crucibles were chilled in furnace, dry cut into two halves and photographed. The penetration depth of corrosive medium was evaluated by visual observation and then by use argentometry. The modifications of lateral sections of the crucible's potsherd were also evaluated.

The following chemical equations can be used for reviewing the ability of chemical reactions pursuant to thermodynamic analysis of corrosive system $\mathrm{NaCl}-\left(\mathrm{SiO}_{2}-\mathrm{Al}_{2} \mathrm{O}_{3}\right)$ between $0{ }^{\circ} \mathrm{C}$ and $1000^{\circ} \mathrm{C}$ : 
Table II - Comparison of the properties of refractory lining $\mathrm{A}$ and $\mathrm{B}[3]$.

[Tabela II - Comparação entre as propriedades dos revestimentos $A$ e $B$ [3].]

\begin{tabular}{lcc}
\hline \multicolumn{1}{c}{ Properties } & Lining A & Lining B \\
\hline Cold compression strength $[\mathrm{MPa}]$ & 60 & 60 \\
Volume weight $\left[\mathrm{kg} \cdot \mathrm{m}^{-3}\right]$ & 2250 & 2150 \\
Apparent porosity $[\%]$ & 12 & 14 \\
Heat strain resistance $\left[{ }^{\circ} \mathrm{C}\right] *$ & 1440 & 1100 \\
\hline${ }^{*}$ Standard Test used
\end{tabular}

Table III - Comparison of the properties of salts $\mathrm{NaCl}$ and $\mathrm{KCl}[4]$.

[Tabela III - Comparação entre as propriedades dos sais $\mathrm{NaCl}$ e $\mathrm{KCl}$ [4].]

\begin{tabular}{lcc}
\hline & $\mathrm{NaCl}$ & $\mathrm{KCl}$ \\
\hline Molar weight M $\left[\mathrm{g} \cdot \mathrm{mol}^{-1}\right]$ & 58.43 & 74.55 \\
Density $\rho\left[\mathrm{g} \cdot \mathrm{cm}^{-3}\right]$ & 2.165 & 1.984 \\
Melting temperature $\mathrm{t}_{\text {top }}\left[{ }^{\circ} \mathrm{C}\right]$ & 800.4 & 771.0 \\
Boiling temperature $\mathrm{t}_{\mathrm{var}}\left[{ }^{\circ} \mathrm{C}\right]$ & 1413 & 1420 \\
Surface tension $\sigma\left[\mathrm{mN}^{-1} \mathrm{~m}^{-1}\right]$ & 113.8 & 97.4 \\
Diameter - anion $[\AA]$ & 1.81 & 1.81 \\
Diameter - cation $[\AA]$ & 0.98 & 1.33 \\
\hline
\end{tabular}

$$
\begin{aligned}
& 2 \mathrm{NaCl}+\mathrm{K}_{2} \mathrm{O} \rightarrow \mathrm{Na}_{2} \mathrm{O}+2 \mathrm{KC} \\
& 2 \mathrm{NaCl}+\mathrm{K}_{2} \mathrm{O} \cdot 2 \mathrm{SiO}_{2} \rightarrow 2 \mathrm{KCl}+\mathrm{Na}_{2} \mathrm{O} \cdot 2 \mathrm{SiO}_{2} \\
& 6 \mathrm{KCl}+\mathrm{Fe}_{2} \mathrm{O}_{3}+3 \mathrm{Al}_{2} \mathrm{O}_{3} \cdot 2 \mathrm{SiO}_{2} \rightarrow \\
& 2 \mathrm{FeCl}_{3}+3 \mathrm{~K}_{2} \mathrm{O}_{2} 3 \mathrm{Al}_{2} \mathrm{O}_{3} .2 \mathrm{SiO}_{2}
\end{aligned}
$$

The process of fire-clay refractory lining corrosion can be characterized also by chemical reactions A-C. The existence of ion pairs $\mathrm{K}^{+}: \mathrm{Cl}^{-}$is possible in regard to thermodynamic stability of $\mathrm{KCl}$ in this system.

$\mathrm{NaCl}$ and $\mathrm{KCl}$ show high stability in oxidizing atmosphere and structure of ion pairs remains after melting. $\mathrm{KCl}$ looks to be more stable phase in regard to thermodynamic stability in connection which oxide system $\mathrm{SiO}_{2}-\mathrm{Al}_{2} \mathrm{O}_{3}-\mathrm{X}\left(\mathrm{X}=\mathrm{K}_{2} \mathrm{O}\right.$, $\mathrm{Na}_{2} \mathrm{O}, \mathrm{CaO}, \mathrm{Fe}_{2} \mathrm{O}_{3}, \mathrm{TiO}_{2}, \mathrm{MgO}$ ) and in conditions of crucible test [5].

\section{RESULTS AND DISCUSSION}

The weight reduction of corrosive medium was calculated as the difference between the weight of crucible with corrosive medium and crucible after the test. It equals to evaporation corrosive medium into the atmosphere during the test. Table IV shows different weight reduction of corrosive medium. More intense evaporation of both
Table IV - The weight reduction of corrosive medium during crucible test.

[Tabela IV - Redução de peso dos meios corrosivos durante o teste em cadinho.]

\begin{tabular}{ccc}
\hline Lining & $\begin{array}{c}\text { Corrosive } \\
\text { Lmedium }\end{array}$ & $\begin{array}{c}\text { The weight reduction of } \\
\text { corrosive medium [wt.\%] }\end{array}$ \\
\hline \multirow{2}{*}{$\mathrm{A}$} & $\mathrm{NaCl}$ & 16.10 \\
& $\mathrm{KCl}$ & 24.36 \\
$\mathrm{~B}$ & $\mathrm{NaCl}$ & 33.34 \\
& $\mathrm{KCl}$ & 40.00 \\
\hline
\end{tabular}

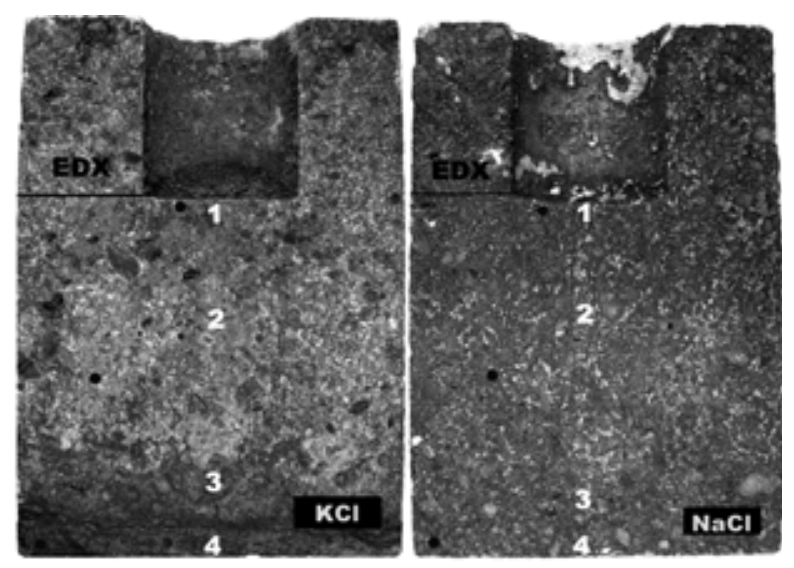

Refractory lining A

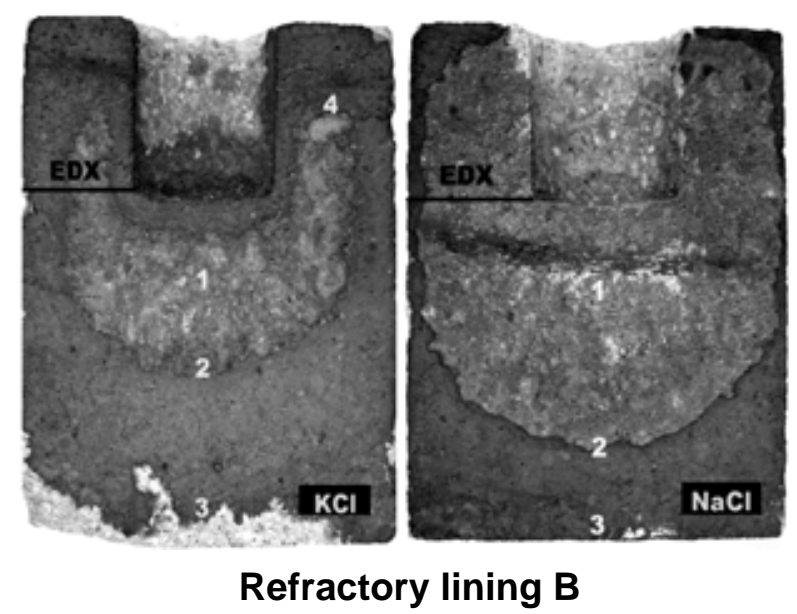

Figure 3: The penetration depth of $\mathrm{NaCl}$ and $\mathrm{KCl}$ - macroscopic analysis.

[Figura 3: Nível de penetração de $\mathrm{NaCl}$ e de $\mathrm{KCl}$ - análise microscópica.]

corrosive media was obtained if the crucible of lining B was used. Obviously, the corrosive medium preferentially reacts with lining A. The macroscopic analysis (Fig. 3), and evaluation of individual corrosive medium penetration depth confirm this fact.

The quality of macroscopic analysis can be improved by using argentometry. It is a method based on the use of silver nitrate, $\mathrm{AgNO}_{3}$. One half of cut crucible is painted with a dilute solution of the $\mathrm{AgNO}_{3}$. It reacts with chlorine ions, and white coagulation of silver chloride $\mathrm{AgCl}$ is formed. The 
coagulation step by step became brown, until turn nearly black due to sunlight. The following chemical reactions can be expected for reviewing the penetration depth [6].

$$
\begin{aligned}
& \mathrm{AgNO}_{3}(a q)+\mathrm{NaCl}(a q) \rightarrow \mathrm{AgCl}(s)+\mathrm{NaNO}_{3}(a q) \\
& \mathrm{AgNO}_{3}(a q)+\mathrm{KCl}(a q) \rightarrow \mathrm{AgCl}(s)+\mathrm{KNO}_{3}(a q)
\end{aligned}
$$

The results of macroscopic analysis confirm different ways of the penetration of corrosive medium into a wall of crucible. The penetration of $\mathrm{NaCl}$ is more significant as it of $\mathrm{KCl}$ (Table V). The modifications in not penetrated structure of the crucible were not observed by optic microscope analysis. Compact reaction layer occurs on the boundary line crucible - corrosive medium. The layer is saturated with melting corrosive medium and also potentially with the product of reaction between the melting and oxide components of the crucible. The compactness of penetrated area with closed pores is below it of the layer on the boundary line crucible - corrosive medium. The compactness of external border of the crucibles is also low with bigger and connected pores.

Table V - Macroscopic evaluation of penetration depth into lining.

[Tabela V - Avaliação macroscópica do nivel de penetração no revestimento.]

\begin{tabular}{cccc}
\hline Lining & $\begin{array}{c}\text { Corrosive } \\
\text { medium }\end{array}$ & $\begin{array}{c}\text { The place of } \\
\text { measurement }\end{array}$ & $\begin{array}{c}\text { Mean } \\
\text { penetration } \\
\text { depth [mm] }\end{array}$ \\
\hline \multirow{3}{*}{$\mathrm{A}$} & \multirow{2}{*}{$\mathrm{NaCl}$} & side wall & 17.8 \\
& & bottom & 50.5 \\
& $\mathrm{KCl}$ & side wall & 17.8 \\
& & bottom & 47.5 \\
& \multirow{3}{*}{$\mathrm{NaCl}$} & side wall & 16.0 \\
& & bottom & 29.0 \\
& \multirow{3}{*}{$\mathrm{KCl}$} & side wall & 12.0 \\
& & bottom & 22.0 \\
\hline
\end{tabular}

The chemical analysis of three areas was carried out: 1 - boundary line - the layer between corrosive medium and crucible, about $2 \mathrm{~mm}$ from the hole of crucible; 2 - penetrated area, about $20 \mathrm{~mm}$ from the hole; 3 - the area of crucible unaffected by penetration, about $48 \mathrm{~mm}$ from the hole.

Figs. 4 and 5 show different process of the corrosion of refractory lining A and B, respectively. Fig. 4 shows the concentration of $\mathrm{Na}$ and $\mathrm{Cl}$ in both standards of refractory lining (A, B) with $\mathrm{NaCl}$ as corrosive medium. The concentration of both elements is stable with linear course in lining A or uniformly decreases in lining B from the hole to external wall of the crucible. Fig. 5 shows the concentration of $\mathrm{K}$ and $\mathrm{Cl}$ in both standards of refractory lining with $\mathrm{KCl}$ as corrosive medium. The concentration of both elements moderately decreases from the hole to external wall of the

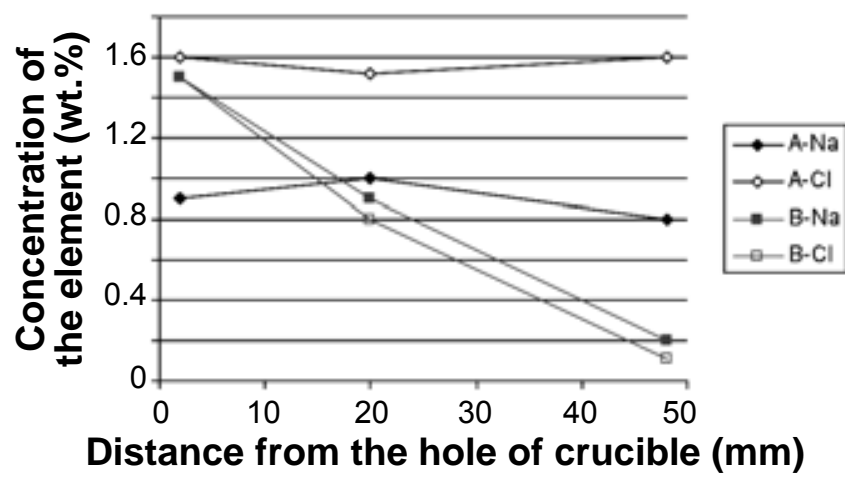

Figure 4: Penetration of the elements $\mathrm{Na}$ and $\mathrm{Cl}$ into linings $\mathrm{A}$ and B (corrosive medium 100\% $\mathrm{NaCl}$ ).

[Figura 4: Penetração dos elementos $\mathrm{Na}$ e $\mathrm{K}$ nos revestimentos $\mathrm{A}$ e $B$ (meio corrosivo $100 \% \mathrm{NaCl}$ ).]

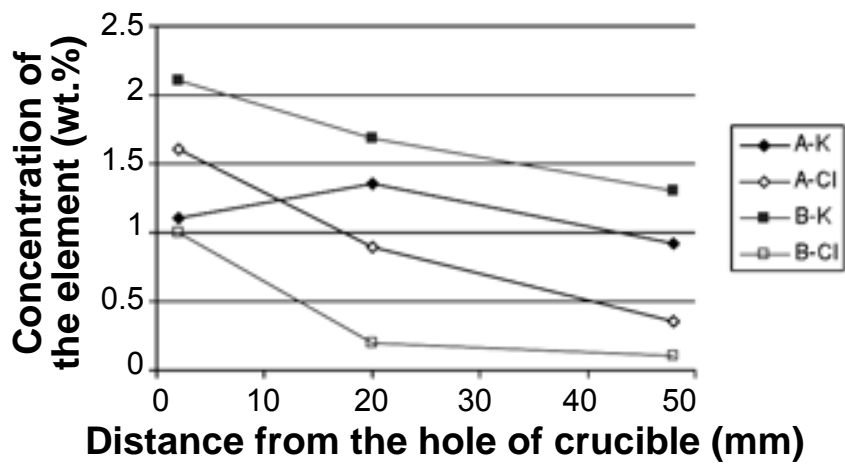

Figure 5: Penetration of the elements $\mathrm{K}$ and $\mathrm{Cl}$ into linings $\mathrm{A}$ and $\mathrm{B}$ (corrosive medium $100 \% \mathrm{KCl}$ ).

[Figura 5: Penetração dos elementos $\mathrm{K}$ e Cl nos revestimentos A e $B$ (meio corrosivo $100 \% \mathrm{KCl}$ ).]

crucible in both standards of refractory lining.

After microscopic analysis, the specimens were analyzed by semiquantitative local EDX with the view of exact study of the corrosion process. The selected surface $\left(\begin{array}{ll}100 & 100\end{array}\right)$ $\mu \mathrm{m}^{2}$ was used for analysis of composition of the matrix in intergranular space and the grains of the opening material. The analysis confirmed marginal diffusion of $\mathrm{Na}, \mathrm{Cl}$ and $\mathrm{K}$ ions into the grains of mullite in accordance with literary sources [7]. The penetration of melted corrosive medium into the lining went per matrix in intergranular space. The EDX analysis was also used to provide the evaluation of possible diffusion of corrosive medium into the grains of the fire-clay lining. Fig. 6 shows microstructure of lining B after corrosive test about $5 \mathrm{~mm}$ from the boundary line with the marking of the surface, selected for evaluation.

The results of EDX analysis indicated the possibility of chemical reactions $\mathrm{A}-\mathrm{C}$ between $\mathrm{SiO}_{2}-\mathrm{Al}_{2} \mathrm{O}_{3}$ system of refractory lining of crucible and melted corrosive medium $\mathrm{NaCl}$ or $\mathrm{KCl}$. The thermodynamic analysis of this mixed system suggests some possible reactions. The run of reactions depends on their kinetics, however. It is assumed that, in general, occurs adsorption of chloride ions on the surface of oxide phases in the event of interactions of chloride melting 


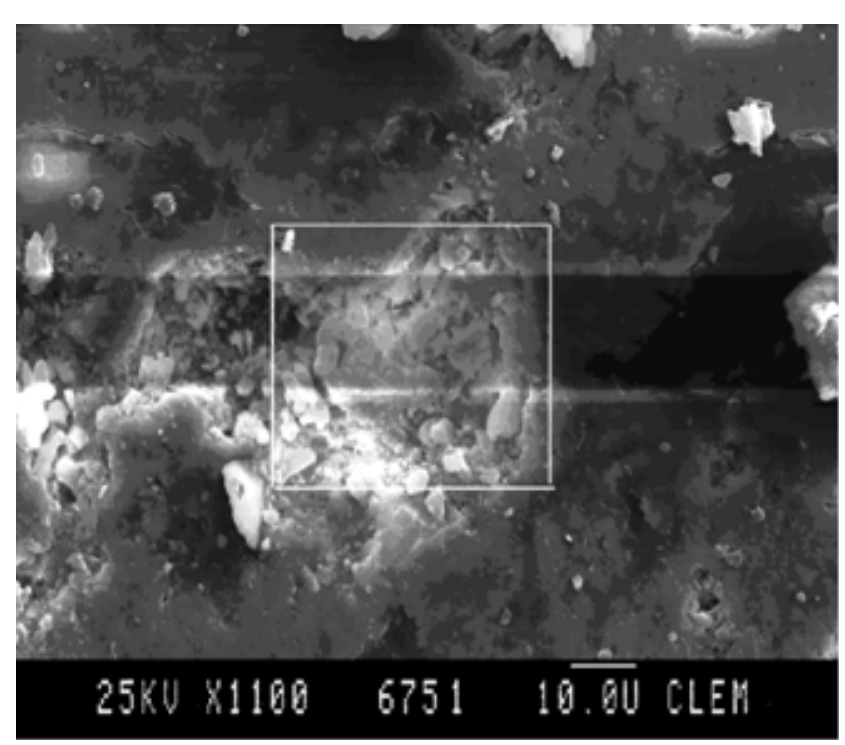

Figure 6: SEM micrograph of lining $B$ in penetrated area after corrosive test about $5 \mathrm{~mm}$ from the boundary.

[Figura 6: Micrografia obtida em microscópio eletrônico de varredura do revestimento $B$ na área penetrada após teste de corrosão a $5 \mathrm{~mm}$ da borda.]

on the interface of solid-solid phases [8].

The possibility of the diffusion of melted corrosive medium into volume of fire-clay grains was evaluated. The results of semiquantitative EDX analysis, presented in Table VI confirm diffusion in the surface layer of the grains. The diffusion of $\mathrm{Cl}$ and $\mathrm{Na}$ ions into grain in the event of interaction with $\mathrm{NaCl}$ can be expected. Only surface layer of the grain is penetrated with $\mathrm{Cl}$ and $\mathrm{K}$ ions if $\mathrm{KCl}$ melting is used. The ions of $\mathrm{Na}$ or $\mathrm{K}$ could get into grains also in the production process (first of in manufacturing operations of raw material at high temperature). The soothing of grains with chlorine ions is improbable in that way. The diffusion of ion pairs $\mathrm{Na}^{+}: \mathrm{Cl}^{-}$through the pores and cracks is supposed during crucible tests. The literary sources [9] relate to dimensions of ion pairs $\mathrm{Na}^{+}: \mathrm{Cl}^{-}$and $\mathrm{K}^{+}: \mathrm{Cl}^{-}$confirm this supposition. Theoretical internuclear radius of $\mathrm{NaCl}$ is $\mathrm{r}_{\mathrm{NaCl}}=$ $0.276 \mathrm{~nm}$, and it of $\mathrm{KCl}$ is $\mathrm{r}_{\mathrm{KCl}}=0.314 \mathrm{~nm}$. Higher activity of ion pair $\mathrm{Na}^{+}: \mathrm{Cl}^{-}$is supposed during corrosion tests.

Recent reviews show that, despite much interest, the cause of corrosion mechanism between melting chloride corrosive medium and oxide refractory lining is published only on a small scale. The examples in the literature are
Table VII - Physical properties of pure chlorides $\mathrm{NaCl}$ at $\mathrm{KCl}$ at $850^{\circ} \mathrm{C}[9]$.

[Tabela VII - Propriedades fisicas dos cloretos puros $\mathrm{NaCl}$ e $\mathrm{KCl}$ a $850^{\circ} \mathrm{C}$ [9].]

\begin{tabular}{cccc}
\hline \multirow{2}{*}{$\begin{array}{c}\text { Composition/ } \\
\text { Melting } \\
\text { temperature }\left[{ }^{\circ} \mathrm{C}\right]\end{array}$} & $\begin{array}{c}\text { Dynamic } \\
\text { viscosity } \\
{[\mathrm{mPa} . \mathrm{s}]}\end{array}$ & $\begin{array}{c}\text { Surface } \\
\text { tension } \\
{\left[\mathrm{mN} . \mathrm{m}^{-1}\right]}\end{array}$ & $\begin{array}{c}\text { Density } \\
{\left[\mathrm{g} . \mathrm{cm}^{-3}\right]}\end{array}$ \\
\hline $\mathrm{NaCl} / 800$ & 1.211 & 110.8 & 1.532 \\
$\mathrm{KCl} / 771$ & 0.931 & 93.0 & 1.484 \\
\hline
\end{tabular}

restricted to physical influences, affecting the course of interactions: porosity of masonry (bricks, lining), adsorption, wetting power and other physical properties of the melting. Obtained results suggest that we can regard to chemical reactions. However, it will be necessary to review their kinetics. In general, the wetting power of the oxide refractory lining with chloride corrosive medium is very strong. Their adsorption on the surface of the oxide lining is mostly taken in account. The references regarding physical properties of melting chloride corrosive medium are infrequent and outof-date [10]. The density, surface tension and viscosity of melting medium are determining factors for their intensive penetration. Selected physical properties of pure melting of $\mathrm{NaCl}$ and $\mathrm{KCl}$ at temperature $850^{\circ} \mathrm{C}$ are in table VII.

Fig. 7 shows the results of semiquantitative EDX analysis of the elements $\mathrm{K}, \mathrm{Na}$ and $\mathrm{Cl}$ reduced to chlorides $\mathrm{NaCl}$ and $\mathrm{KCl}$. Different penetrations of both compounds

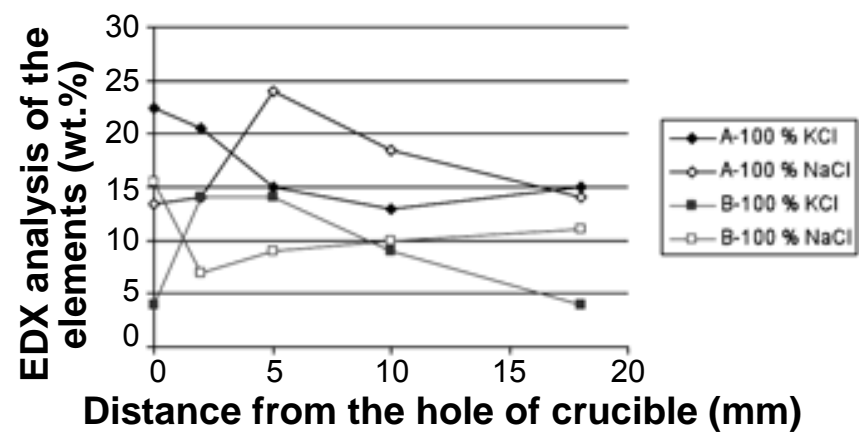

Figure 7: Penetration of chlorides $\mathrm{KCl}$ and $\mathrm{NaCl}$ into linings $\mathrm{A}$ and $\mathrm{B}$ - semiquantitative EDX analysis.

[Figura 7: Penetração dos cloretos $\mathrm{KCl}$ e $\mathrm{NaCl}$ nos revestimentos A e $B$ - análise EDX semi-quantitativa.]

Table VI - Semiquantitative EDX analysis of crucible (lining B) grains after crucible test. [Tabela VI - Análise semi-quantitativa EDX dos grãos do cadinho (revestimento B) após o teste no cadinho.]

\begin{tabular}{ccccccccccc}
\hline & $\begin{array}{c}\text { Analyzed } \\
\text { part of } \\
\end{array}$ & \multicolumn{10}{c}{ Semiquantitative EDX analysis [wt.\%] } \\
\cline { 3 - 10 } & grain & $\mathrm{Al}$ & $\mathrm{Si}$ & $\mathrm{Mg}$ & $\mathrm{Na}$ & $\mathrm{Cl}$ & $\mathrm{K}$ & $\mathrm{Ca}$ & $\mathrm{Ti}$ & $\mathrm{Fe}$ \\
$100 \%$ & edge & 12.0 & 68.1 & 0.0 & 0.1 & 0.9 & 13.3 & 0.0 & 2.2 & 3.3 \\
$\mathrm{KCl}$ & middle & 14.9 & 67.4 & 0.0 & 0.0 & 0.0 & 15.3 & 0.1 & 0.7 & 1.6 \\
$100 \%$ & edge & 16.6 & 75.9 & 0.0 & 0.7 & 1.3 & 1.2 & 0.2 & 2.3 & 1.9 \\
$\mathrm{NaCl}$ & middle & 16.1 & 70.9 & 0.0 & 0.4 & 0.5 & 0.6 & 0.2 & 9.1 & 2.2 \\
\hline
\end{tabular}


into refractory lining are visible. The variation in content of particular elements was obtained in all four combinations of lining and melting (A-NaCl, A-KCl, B-NaCl, B-KCl) measured about $2 \mathrm{~mm}$ from the hole of crucible according to plot in Fig. 7. This area is apparently the layer of reaction. The chlorides with elements of refractory lining can react there, for example, in accordance with equations A-C.

\section{CONCLUSIONS}

The weight reduction-evaporation of $\mathrm{KCl}$ is more significant for both linings in comparison with $\mathrm{NaCl}$. Both chlorides penetrate into linings $\mathrm{A}$ in preference. $\mathrm{NaCl}$ shows more significant penetration and chemical interaction in penetrated area. The variance of structure of crucible walls were not obtained by microscopic analysis. The concentration of observed elements is stable without significant variations. The ions of $\mathrm{K}$ penetrate into the grains of the lining more intense than the $\mathrm{Na}$ ions. EDX analysis confirms creation of the reaction layer between chlorides and elements of refractory lining.

\section{ACKNOWLEDGEMENTS}

This work was supported by the Slovak Grant Agency for Science VEGA 1/0643/11 and by Agency of ME SR for ŠF EU (Project No. ITMS 26220120038 and ITMS 26220220053).

\section{REFERENCES}

[1] E. Grambálová, Dr. Thesis, Faculty of Metallurgy, Technical University of Košice (2010).

[2] Available from: www.chifis1.inupv.it/materials/ ChFisMat/phd5.ppt, [online, cited 10 May] (2010).

[3] Available from: http://www.simonsen.eu/PRODUCTS/ alubar-1100.pdf, [online, cited 10 May] (2009).

[4] J. Vohlídal, K. Štulík, A. Julák, Chemické a analytické tabulky, Grada Publishing, Praha, Czech Republic (1999).

[5] V. Daněk, M. Chrenková, A. Silný, Elektrolytická výroba hlinika, Ústav anorganickej chémie SAV, Bratislava, Slovakia (1997).

[6] E. Grambálová, "Makroskopické vyhodnocovanie koróznej skúšky: korundový žiarobetón - $\mathrm{NaCl}$, Medzinárodná vedecká konferencia , Žiaromateriály, pece a tepelné izolácie", Patria, Štrbské pleso, Vysoké Tatry (Apríl 2006) pp. 216-220.

[7] P. Vadász, O. Kamod’a, I. Čipková, InterCeram Refractories manual 58 (2009) 41-46.

[8] K. L. Luthra, O. H. LeBlanc Jr., J. Phys. Chem. 88 (1984) 1896-1901.

[9] L. C. Pauling, General chemistry, W. H. Freeman, San Francisco, USA (1988).

[10] G. J. Janz. et al., "Molten Salts: Electrical Conductance, Density, Viscosity and Surface Tension Data", J. Phys. Chem. Ref. Dat. 1 (1972) 3.

(Rec. 24/01/2013, Ac. 12/10/2013) 